\title{
Comparison of Characteristics of P-Wave Detection in ECG with Wireless Patch Electrodes
}

\author{
Young Chang Cho*, Min Soo Kim*, and Jeong Oh Yoon ${ }^{* * *}$
}

\begin{abstract}
P}$-wave characteristic in the human electrocardiogram (ECG) is important in the diagnosis of atrial conduction pathology. In this paper, we measured an ECG signal from patient with cardiovascular disease using one lead ECG electrode system which is based on the wireless cardiac monitoring system. And we detected a $\mathrm{P}$-wave in ECG signal using the complex-valued continuous wavelet transforms (CWT) according to two kinds of patch type electrodes such as an existing narrow patch type electrode and the improved wide patch type electrode presented in this paper. Also, we compared the characteristics in detecting the $\mathrm{P}$-wave in terms of the magnitude and the width of $\mathrm{P}-$ waves. From the results of comparison we found that the width and the magnitude of $\mathrm{P}$-wave detected using the wide patch type electrode is improved to be interpreted easier compared to those using the narrow patch type electrode. Furthermore, we have also proven that the complex-valued CWT can be used as a robust detector for $\mathrm{P}-$ wave in ECG signal analysis.
\end{abstract}

Key Words : P-wave; electrocardiogram (ECG); wireless patch type electrode; one lead; complex-valued continuous wavelet transform (CWT)

\section{Introduction}

The analysis of the electrocardiogram (ECG) is a well-known non-invasive technique to detect the electrical heart activity. Abnormal heart cycle is reflected in the ECG by P-wave, QRS complex and $\mathrm{T}$ wave. Several clinical studies connect certain P-wave properties such as its width and morphology, with anomalies in the electrical atrial conduction and atrial pathology. The relation between the $\mathrm{P}$-wave morphology and the interatrial delay has been studied in [1, 2]. Recently, it has

* 경운대학교 항공정보통신공학과, 제 1 저자

** 경운대학교 항공정보통신공학과, 제 2 저자

*** 경운대학교 항공정보통신공학과, 교신저자 (e-mail:joyun@ikw.ac.kr) been clearly verified how $\mathrm{P}$-wave morphology depends upon which of three interatrial routes the conduction from right to left atrium has utilized [3]. The analysis of the $\mathrm{P}-$ wave obtained from Frank leads and its relation to atrial fibrillation is reported in [4-6]. The magnitude and width of the $\mathrm{P}$-waves are smaller than those of the QRS complexes and $\mathrm{T}$ waves, So their study requires more sophisticated computation techniques. In order to improve the performance in obtaining the $\mathrm{P}-$ wave, a different approach such as using the wide patch type electrode is needed. The patch type electrode constantly records the heart's electrical activity and is designed to be worn comfortably during normal daily activities, including sleep. The ease of use and inconspicuousness of the patch electrode helps 
increase the likelihood that a patient will wear the device for the entire prescribed monitoring period. Patch ECG electrode system offers patient friendly, non-obtrusive, electrode and lead wire free recording environment. In addition to monitoring one lead ECG signal[7, 8], patch electrode also monitors the contact impedance, providing real time information on the sensor contact quality.

But, it is difficult to observe the $\mathrm{P}^{-}$-wave with the existing narrow patch type electrode because the size of the electrode is not sufficient to measure $\mathrm{P}-$ wave obviously which is usually small both in magnitude and in width relative to other signal components such as $\mathrm{R}$-wave and $\mathrm{T}$-wave. So, it is necessary to use an additional method to enhance the magnitude and width of $\mathrm{P}^{-}$wave to be detected accurately.

The CWT can decompose a signal into the whole range of scales and positions[9-11], instead of a subset of discrete values as in DWT, which can help disclose more detail information. Usually, the DWT leads to a less redundant decomposition, which makes it efficient to compress and reconstruct a signal or image. Independent to the P-wave width measurements, morphologic analyses have been implemented in the assessment of $\mathrm{P}^{-}$wave characteristics. Hence the $\mathrm{CWT}$ is appropriate for an analysis of the $\mathrm{P}-$ wave detection.

In this paper, we presented the wireless one lead wide patch type electrode to improve the morphology of $\mathrm{P}$-wave. And we proposed the continuous wavelet transform (CWT) based approach to extract useful properties such as the edge and high frequency information in morphology of $\mathrm{P}-$ wave for detection.

\section{Materials and Methods}

For the chronic patients with cardiovascular disease who live alone, it is necessary to constantly monitor their physiological parameters, especially the
ECG, to effectively prevent and control their health conditions. The one lead ECG signal is recorded using two kinds of electrodes. Human ECG transmission has been particularly useful for wireless cardiac monitoring system. Nowadays, the infrastructure of RF and mobile phone systems has opened a new transmission medium which establishes access to many database at very low costs[12, 13].

Real-time ECG transmission via mobile phone system has been important in order to provide a direct access to doctors in remote area.

In this paper we use the real-time ECG analog circuit signal acquisition system as shown in Fig. 1. The ECG signal is sampled at a rate of $f=300 \mathrm{~Hz}$.

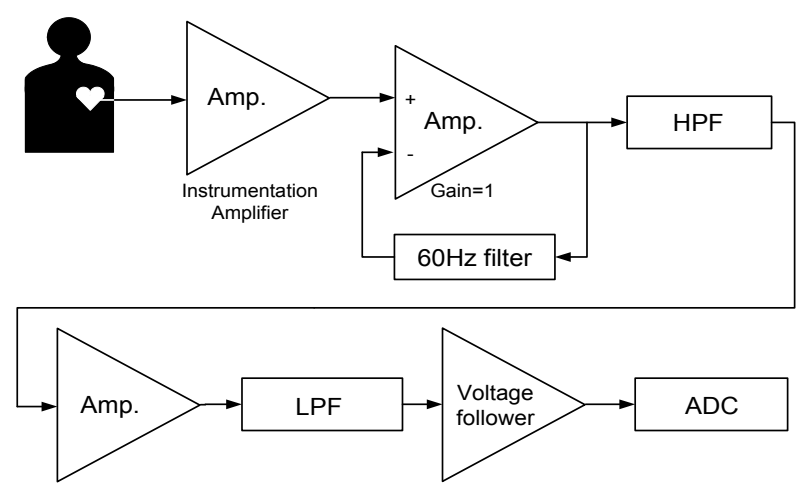

Fig. 1. Block diagram of ECG acquisition system

We use a typical example of a discrete-time ECG signal as shown in Fig. 2. Being a non-stationary signal, the ECG has irregularities, although they may not be periodic and may show up at different intervals.

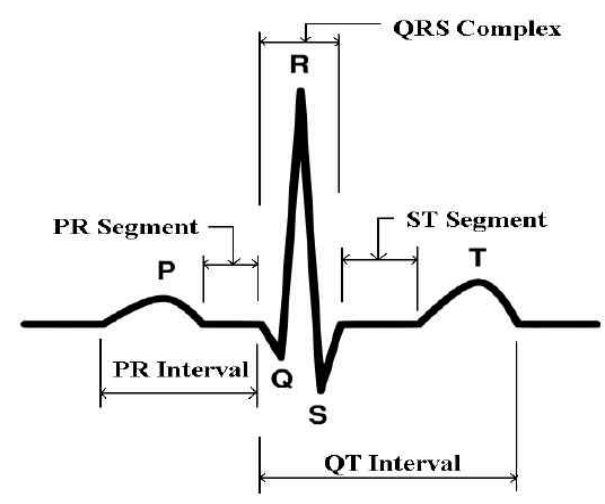


(a) Standard ECG beat

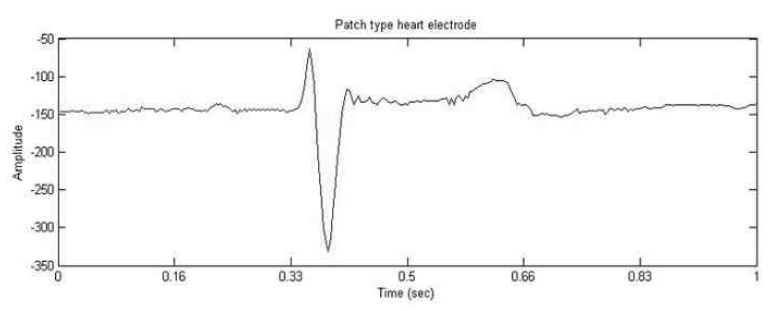

(b) ECG signals measured using the narrow patch type electrode

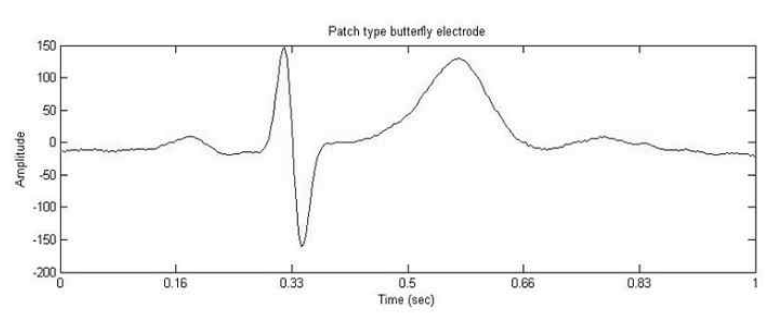

(c) ECG signals measured using the wide patch type electrode

Fig. 2. Standard ECG beat and the measured ECG signals

Fig. 2. shows the waveforms of measured ECG signals. As seen in Fig. 2(b), the waveform of $\mathrm{P}-$ wave in ECG measured by the narrow patch type electrode is narrow in width and small in magnitude compared to the case of the wide patch type electrode shown in Fig. 2(c).

\subsection{Continuous Wavelet Transforms}

The wavelet transform technique is appropriate for studying non-stationary signals. It represents the time-domain signals over different scales, enabling an identification of both large-scale (low frequency) and small-scale (high-frequency) fragments. The CWT does this by having a variable window width, which is related to the scale of observation. Any signal $f(t)$ can be decomposed into a set of base functions $\psi_{s \tau}(t)$ which are called the wavelets. The Continuous Wavelet Transform is obtained by formula [14]:

$$
\gamma(s, \tau)=\int_{-\infty}^{\infty} f(t) \psi_{s, \tau}^{*}(t) d t
$$

where $*$ denotes complex conjugation. The variables $s$ and $\tau$ denote scale and translation. The wavelets are generated from a single base wavelet $\psi$, the so-called mother wavelet, by scaling and translation:

$$
\psi_{s, \tau}(t)=\frac{1}{\sqrt{s}} \psi\left(\frac{t-\tau}{s}\right)
$$

In Eq.(2), $s$ is the scale factor, $\tau$ is translation factor and the factor $\sqrt{s}$ is for energy normalization across different scales. Generally speaking, $\gamma_{s, \tau}(t)$ is obtained by the following process: the basic wavelet (with scale $s=1$ ) is shifted along the signal $f(t)$ and for each value of time shifting $\tau$ the Eq.(1) is computed, then the wavelet window is stretched by factor $s$ (the width of the wavelet window is increased $s$ times) and again shifted along the signal. This process can be repeated over and over again. The larger scale the lower frequency components that are treated.

The advantage of CWT over other time-frequency transformations is that the CWT is not limited to using sinusoidal analyzing functions. Rather, a large selection of localized waveforms can be employed as long as they satisfy predefined mathematical criteria. Coefficients of the CWT are denoted as $\gamma(s, \tau)$ for particular scale(s) and translation $(\tau)$. Scale can be treated as frequency, and translation as time, but considering that larger scales represent the lower frequencies.

Wavelets are basis functions used for expansion. They are characterized by a number of properties that determine their use in the frame of time-frequency localization. Formally, a real-valued function $\psi(t)$ is called a wavelet if it satisfies two constraints defined by 
$\int_{-\infty}^{\infty} \psi(t) d t=0 \quad$ and $\quad \int_{-\infty}^{\infty} \psi^{2}(t) d t=1$

The first part of Eq.(3) states that the wavelet oscillates, the second part says the wavelet must be non-zero somewhere. The properties of wavelets may serve as a key for selection of function for a specific application. Filtering may require symmetrical functions and rational coefficients of filters corresponding to wavelets. The following properties are most discussed in literature: orthogonality, compact (finite) support, rational coefficients of corresponding filters, symmetry, smoothness, and analytic expression $[15,16]$.

\subsection{Real-valued wavelets}

The most used and/or discussed real-valued wavelets are Haar wavelet, a family of Daubechies wavelets, Morlet wavelet, Meyer wavelet, Mexican hat wavelet, a family of Coiflet wavelets, family of Symlet wavelets, and biorthogonal wavelets. The time and frequency resolution of various wavelets differ. The ideal resolution value is represented by an equality curve $\Delta_{t}^{2} \Delta_{\omega}^{2}=0.5$.

The results for selected wavelets can be acquired by G. Mallat [12].

\subsection{Complex-valued wavelets}

The complex-valued wavelets are Complex Gaussian wavelets, Complex Daubechies wavelets, Complex Kingsbury wavelet, Complex Morlet wavelets, Complex Frequency B-spline wavelets, Complex Shannon wavelets. Time and frequency resolution of various complex-valued wavelets differ too. Complex-valued wavelet transform plays a special role in signal analysis. Complex nature of wavelets provides further improvement in signal detection compared to real-valued wavelet analysis. This is possible by using so called the dual-tree processing through cross $^{-}$correlation with real and imaginary parts of wavelets. And the processed complex-valued time-frequency image (CWT) can be further analyzed by detection of significant attributes in its modulus and phase. In this way, not only the waves can be detected but also various shapes of the waves can be distinguished.

\section{Results}

Table 1 shows the comparison of characteristics of $\mathrm{P}$-wave for two kinds of patch type electrodes. The greatest advantage of the patch type electrode is that it's simply designed to use.

$\mathrm{P}$-wave obtained by the improved wide patch type electrode has wider in width and larger in magnitude than that of the conventional narrow patch type electrode.

Table 1. Comparison of characteristics of $\mathrm{P}-$ wave for electrode types

\begin{tabular}{|c|c|c|c|}
\hline $\begin{array}{c}\text { Patch } \\
\text { type } \\
\text { electrode }\end{array}$ & $\begin{array}{c}\text { Size } \\
(\mathrm{cm})\end{array}$ & $\begin{array}{c}\mathrm{P} \text {-wave } \\
\text { average } \\
\text { width } \\
(\mathrm{ms})\end{array}$ & $\begin{array}{c}\mathrm{P} \text {-wave } \\
\text { average } \\
\text { magnitude } \\
(\mathrm{mm})\end{array}$ \\
\hline $\begin{array}{c}\text { narrow } \\
\text { wide }\end{array}$ & $\begin{array}{c}2.5 \times 3.5 \\
8.5 \times 5.5\end{array}$ & $\begin{array}{c}71 \\
107\end{array}$ & $\begin{array}{c}1.607 \\
2.401\end{array}$ \\
\hline
\end{tabular}

Wide patch type electrode improves not only the waveform of $\mathrm{P}^{-}$-wave but also the baseline drift to make the detection of $\mathrm{P}-$ wave easy to be interpreted. We proposed a method to assist to detect the extracted waves effectively, such as $\mathrm{P}^{-}$wave and $\mathrm{R}$-wave in ECG signal. In the discrete wavelet transform (DWT), the wavelet coefficients for scale 1 to 7 is calculated by passing the previous approximation coefficients through the high and low pass filters. According to the power spectra of ECG signal the energies of $\mathrm{P}$-waves are mainly at scale levels 4, 5 and 6. But, baseline drift is serious at scale 7 , so reconstruction coefficients 


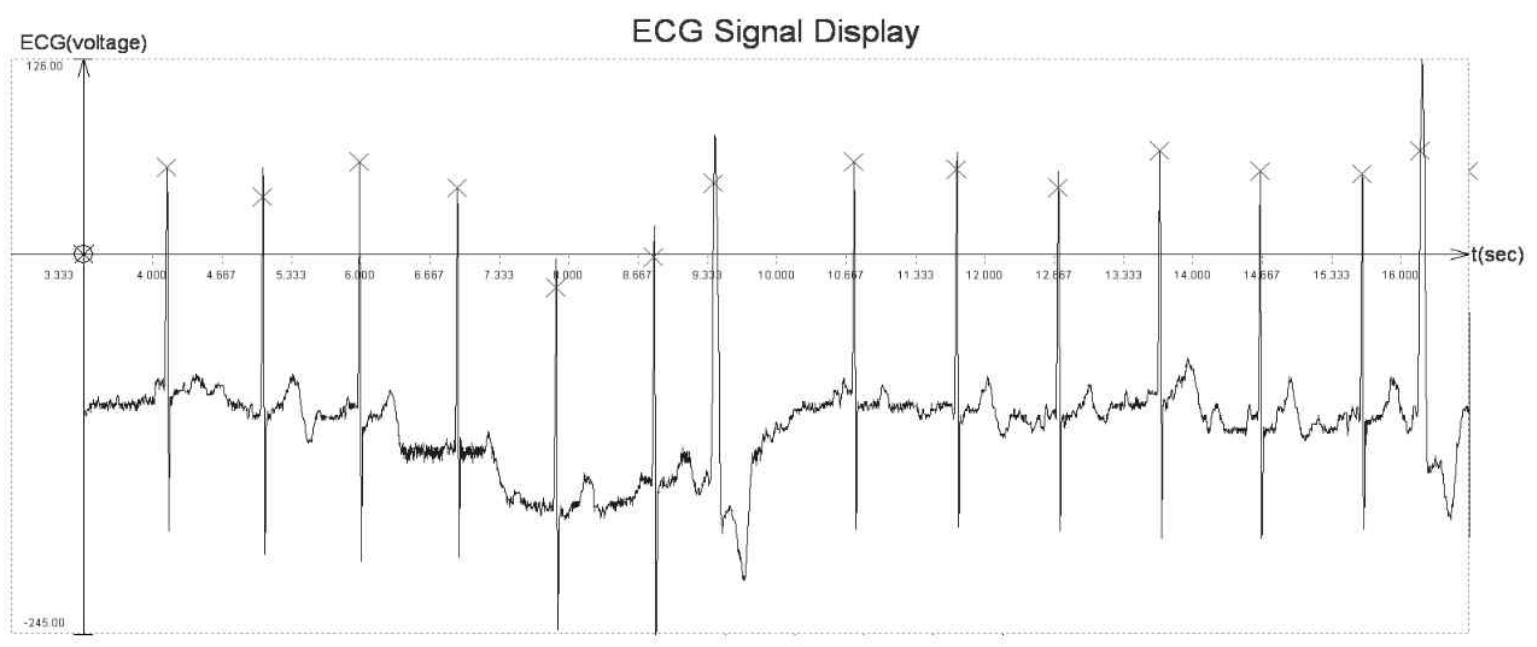

Fig. 3. Example of ECG after the R-wave detection for narrow patch type electrode

$\mathrm{d} 5$ is selected to detect $\mathrm{P}-$ waves.

From Fig. 3, we see that it is difficult to observe $\mathrm{P}-$ wave from the original ECG signal, because the magnitude of $\mathrm{P}$-wave in abnormal ECG is too low and flat. The ECG signal shown in Fig. 4 and Fig. 5 are abnormal signals obtained from the patients with a cardiac arrhythmia using the narrow patch type electrode and wide patch type electrode respectively. In the patch type electrode, $\mathrm{P}-$ wave is reconstructed with the sum of scale 5 and scale 6 by db5 family. From narrow patch type electrode, $\mathrm{P}-$ wave detected with the combined wavelet $(\mathrm{D} 5+\mathrm{D} 6)$ by db5 is shown in Fig. 4.

Fig. 5 shows that it is a little easier to observe

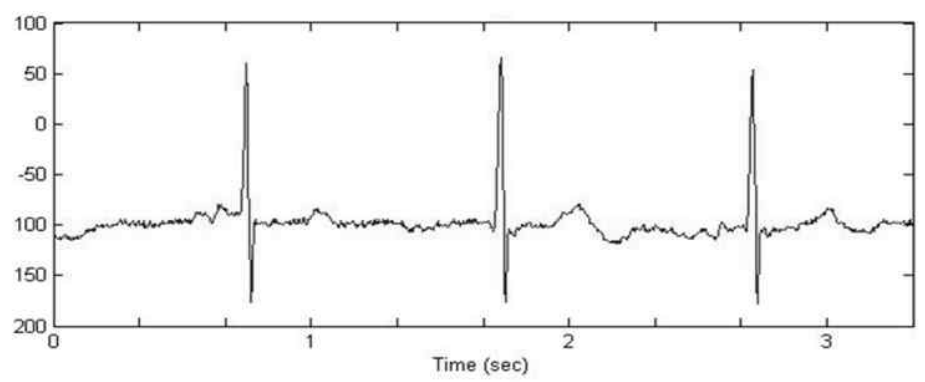

(a) orignal signal

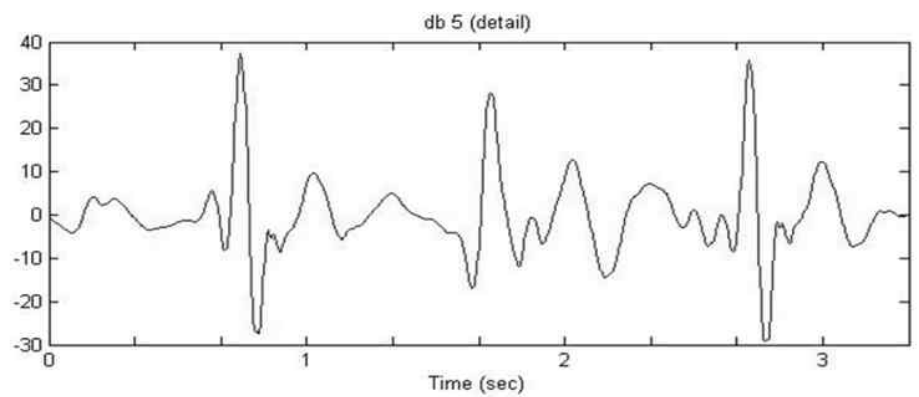

(b) DWT signal

Fig. 4. Detection of $\mathrm{P}-$ wave in ECG using DWT for narrow patch type electrode 


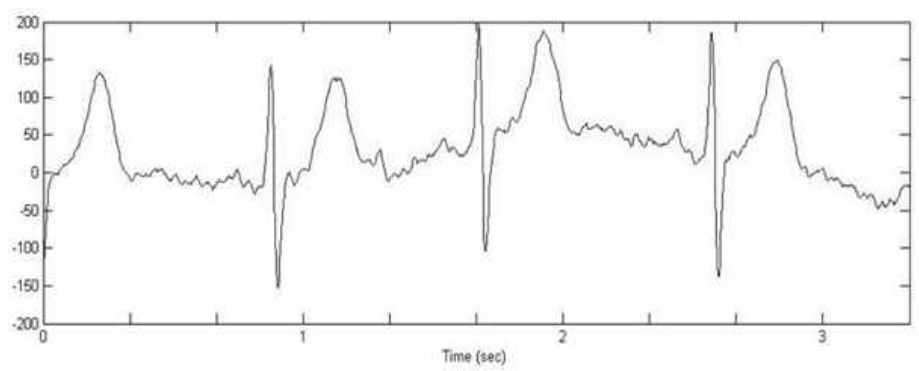

(a) orignal signal

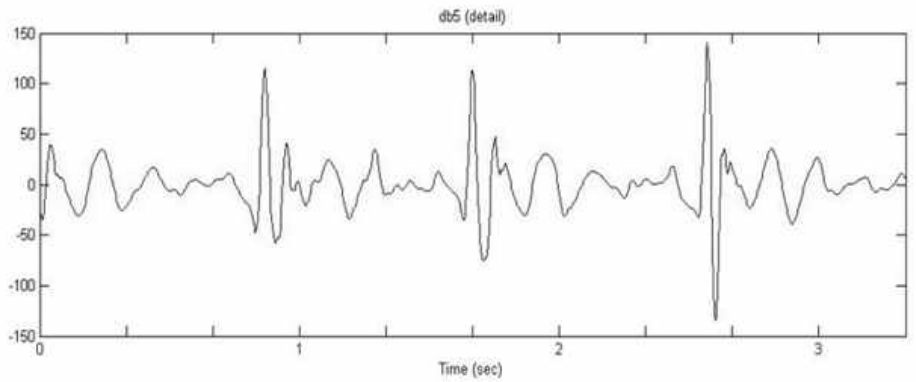

(b) DWT signal

Fig. 5. Detection of $\mathrm{P}^{-}$wave in ECG using DWT for wide patch type electrode

the P-wave in abnormal ECG signal using the wide Morlet 1-0.5 wavelet used in CWT are shown in patch type electrode. Real and Imaginary part of Fig. 6. We can see the difference of the shape of

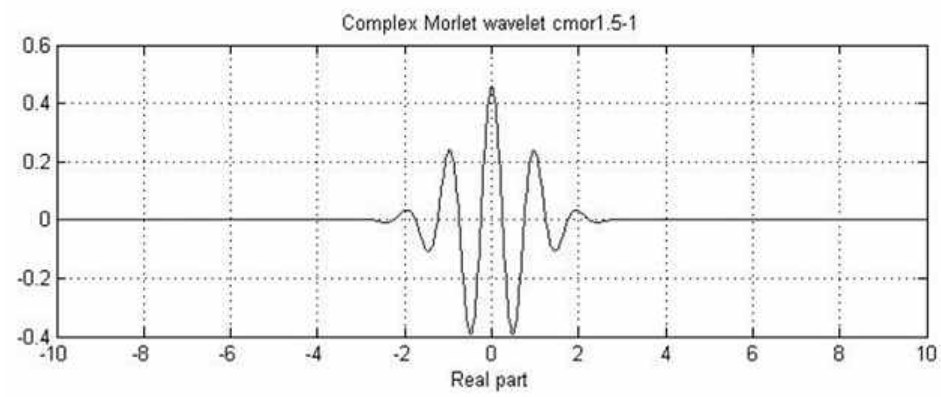

(a) Real part

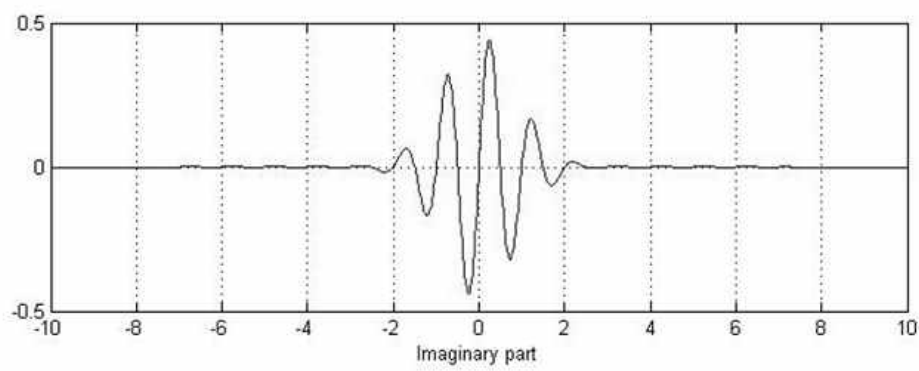

(b) Imaginary part

Fig. 6. Complex Morlet wavelet No.1-0.5. 


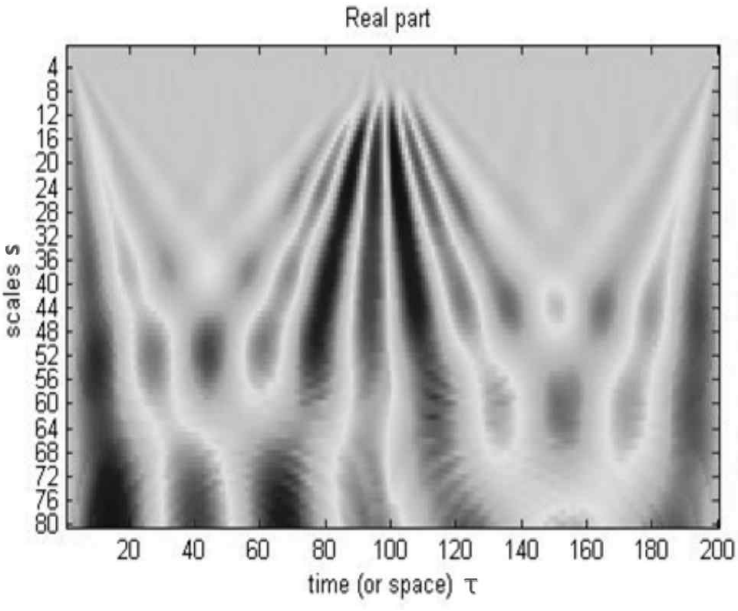

(a)

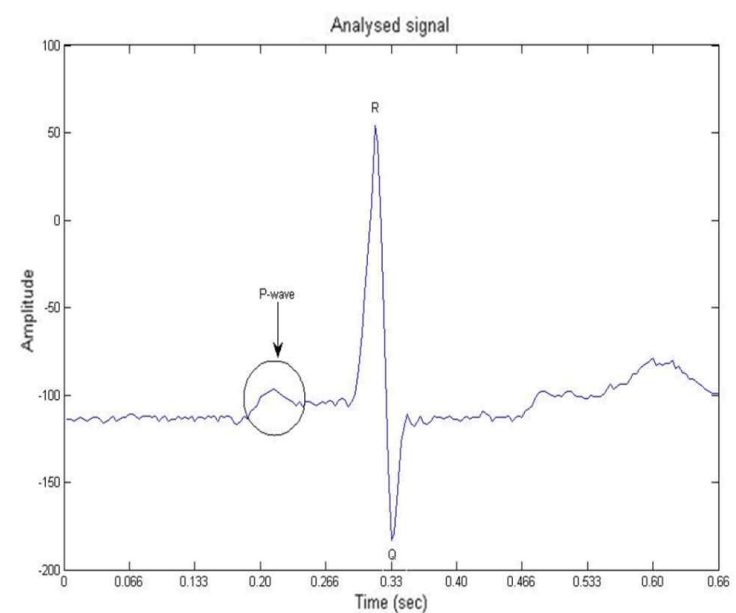

(c)

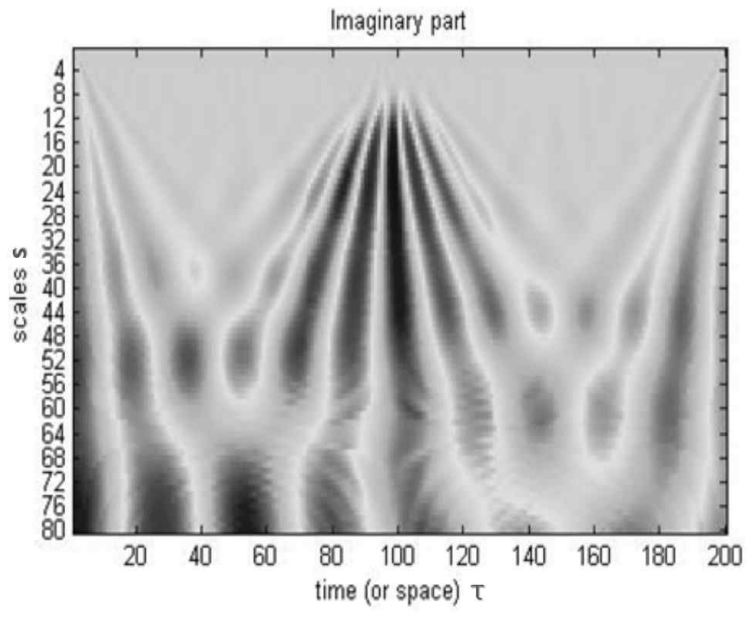

(b)

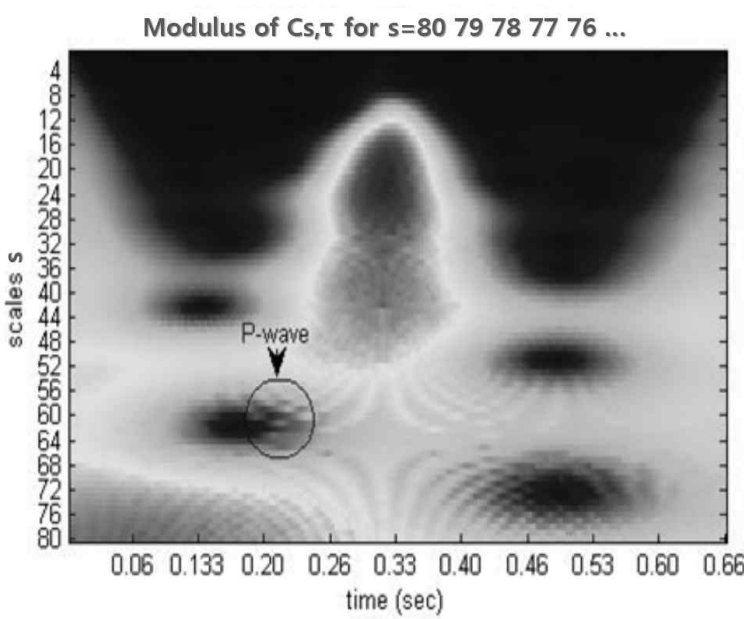

(d)

Fig. 7. Results of CWT from two cycle ECG signal using complex Morlet wavelet No.1-0.5. (a) Absolute value of real part and (b) imaginary part of modulus (c) Detail of the ECG signal for narrow ECG electrode type (d) its modulus

the wavelet basis functions which yields different results in the CWT output representation.

Modulus of time-frequency image (see Fig. 7) displays $\mathrm{P}-$ wave as a single peak centered at $\tau=104$.

The difference between two modulus, the real part and the imaginary part of the CWT are below discussed on detail of the analyzed signal (Fig. $7(\mathrm{a})$-(b)) from narrow patch type electrode. Modulus of time-frequency image (see Fig. 7(d)) displays
P-wave as a single peak centered at $\tau=0.2(\mathrm{sec})$ and $s=60$. Note that the basis wavelet functions are well suited for detecting and localization. In ECG the edge and high frequency information are of paramount importance.

The modulus of CWT using complex Morlet wavelet is shown in Fig. 8. The CWT is indicative of multiple or propagated sources within the heart making respective changes in the measured ECG. This decomposition throws light into the regions of 


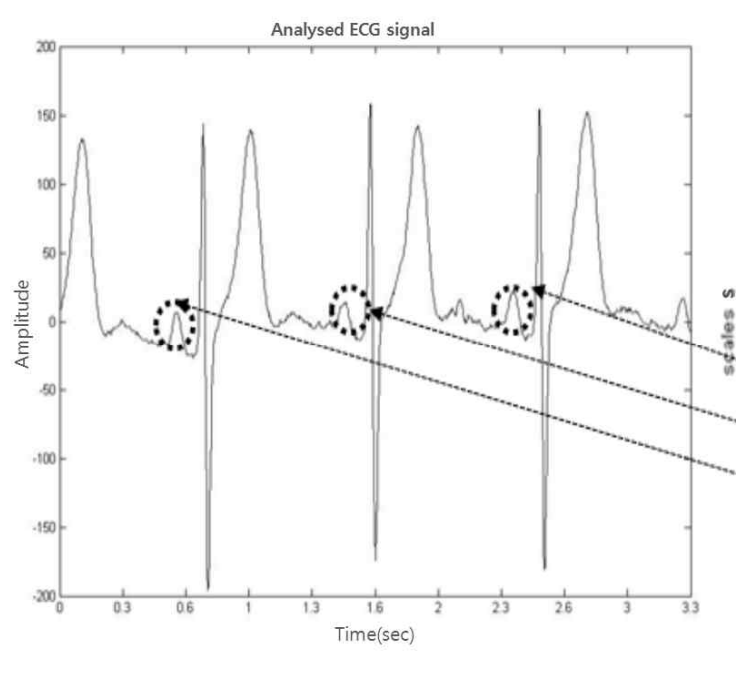

(a)

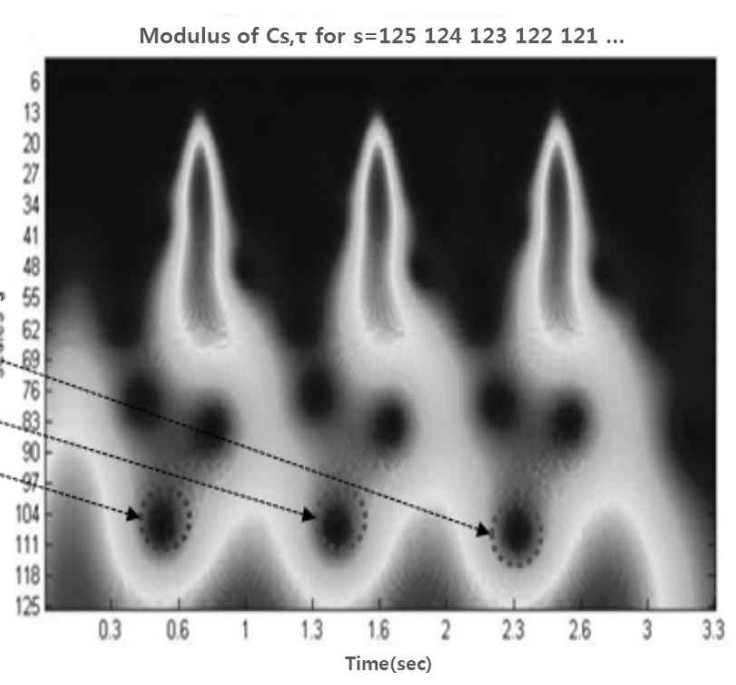

(b)

Fig. 8. Results of CWT using complex Morlet wavelet No.1-0.5 (a) signal with $\mathrm{P}-$ wave in first derivative from wide type electrode (b) its modulus

temporal energy concentrations thus giving an indication of the center of such energy. It may be noted that the Fourier spectrum of the resulting analytic signal is double that of the original signal at positive frequencies and zero at negative frequencies. The energy in the signal is concentrated in a single space/time frequency focus. However, if an additional shifted and attenuated signal is added in time to the same signal, the resulting transform contained additional points of energy concentrations as shown in Fig. 8. However, if a short action potential is added at a similar point, its effect is not noticeable in the transform domain.

The algorithm has been tested on our arrhythmia databases in which every recording is a 15-20 minutes duration, 10 records were tested for P-waves to evaluate our algorithm. In our evaluation of the proposed technique, we have calculated the Sensitivity, the Positive predictability and the Error as follows:

Sensitivity: $S_{e}=\frac{T P}{T P+F N}$

Positive predictability: $P^{+}=\frac{T P}{T P+F P}$
Error: \%error $=\frac{F P+F N}{\text { Total beats }}$

Where, TP indicates true positive(correct detection); FN, false negative(undetected) and FP, false positive(misdetection).

Table 2 shows that our method achieves very good detection performance. This algorithm attains average sensitivity of $99.84 \%$ and average positive

Table 2. Performance of the proposed classification model for test data

\begin{tabular}{|c|c|c|c|c|c|}
\hline Subjects & $\begin{array}{c}\text { Total } \\
\text { beats }\end{array}$ & $\begin{array}{c}\text { FP } \\
\text { beats }\end{array}$ & $\begin{array}{c}\mathrm{FN} \\
\text { beats }\end{array}$ & $\mathrm{P}^{+}(\%)$ & $\mathrm{S}_{\mathrm{e}}(\%)$ \\
\hline subject-1 & 1,200 & 0 & 2 & 100 & 99.81 \\
\hline subject-2 & 1,145 & 0 & 0 & 100 & 100 \\
\hline subject-3 & 1,232 & 7 & 3 & 99.34 & 99.12 \\
\hline subject-4 & 1,022 & 0 & 0 & 100 & 100 \\
\hline subject-5 & 1,099 & 10 & 0 & 99.06 & 100 \\
\hline subject-6 & 1,289 & 0 & 1 & 100 & 99.54 \\
\hline subject-7 & 1,221 & 0 & 0 & 100 & 100 \\
\hline subject-8 & 1,129 & 0 & 3 & 100 & 99.34 \\
\hline subject-9 & 1,094 & 0 & 2 & 100 & 99.43 \\
\hline subject-10 & 1,309 & 0 & 0 & 100 & 100 \\
\hline Average & 1,174 & & & 99.84 & 99.72 \\
\hline
\end{tabular}


predictability of $99.72 \%$ without the need to apply any pretreatment to the original signal.

\section{Conclusions}

$\mathrm{P}$-wave analysis has been used to study the atrial electrical activity in the heart. For studying the variability of the $\mathrm{P}$-wave morphology, the size of a patch type electrode has been developed to improve the detection of $\mathrm{P}-$ wave.

In this work, $\mathrm{P}$-wave morphologic analysis is based on the one lead ECG method and is analyzed using wavelet transforms. We presented the method to improve the morphology of $\mathrm{P}$-wave for increasing the measurement accuracy using wide patch type electrode. And we also proposed the CWT based approach to extract useful information in morphology of $\mathrm{P}$-wave for detection. In its continuous form, the CWT allows a powerful analysis of non-stationary ECG, making it suitable for the high-resolution over a wide range of applications. The ECG detection method can be used for the $\mathrm{P}$-wave detection by the sum of combined scale using CWT. Thus, the clinical use of the methodology proposed in this paper is to be beneficial in the analysis of various heart diseases.

\section{References}

[1] A. Luna, R. Ribot, E. Trilla, J. Julia, J. Garcia, J. Sadurni, J. Riba, F. Sagues, "Electrocardiographic and vector cardio- $^{-}$graphic study of interatrial conduction disturbances with left atrial retrograde activation", J. of Electro., Vol. 18, pp. 1-13, 1985.

[2] J. Daubert, D. Pavin, G. Jauvert, P. Mabo, "Intra- and interatrial conduction delay: Implications for cardiac pacing", Pacing and Clinical Electrophysiology, Vol. 27, pp. 507-525, 2004.
[3] F. Holmqvisti, D. Husser, J. Tapanainen, J. Carlson, R. Jurkko, Y. Xia, R. Havmo, O. Kongstad, L. Toivonen, S. Olsson, P. Platonov, "Interatrial conduction can be accurately determined using standard 12-lead electrocardiography: validation of $\mathrm{p}^{-}$-wave morphology using electro anatomic mapping in man", Heart Rhythm, Vol. 5, pp. 413 - 418, 2008.

[4] P.G Platonov, S. Yuan, E. Hertevig, O. Kongstad, L.V Chireikin, S. Olsson, "Presence of right atrial conduction disturbance in patients with alone atrial fibrillation", Scandinavian Cardiovascular Journal, Vol. 35, pp. 270-279, 2001.

[5] P. Platonov, J. Carlson, M. Ingemansson, A. Roijer, A. Hansson, L. Chireikin, S. Olsson, "Detection of inter-atrial conduction defect with unltered signal averaged $\mathrm{P}-$ wave ECG in patients with lone atrial fibrillation", European Pacing and Clinical Electrophysiology, Vol. 2, pp. 32-41, 2000 .

[6] F. Censi, G. Calcagnini, C. Ricci, R. Ricci RP, M. Santini, A. Grammatico, P. Bartolini, "Pwave morphology assessment by a gaussian functions-based model in atrial fibrillation patients", IEEE Trans on Biom. Eng., Vol. 54, pp. 663-672, 2007.

[7] S. Lobodzinski and M. Laks, "New devices for very long-term ECG monitoring", New Drugs and Technologies in Cardiology, Vol. 19, pp. 210-214, 2012.

[8] L. She, J. Zhao, S. Zhang, G. Wang and G. Wang, "A novel portable one lead ECG monitor with low cost and long time recording based on NUC501", 2010 Chinese Control and Decision Conference, 2010.

[9] M. Mariana, D. Moga and I. Mihalas, "Continuous Wavelet Transform in ECG Analysis. A Concept or Clinical Uses", Connecting Medical Informatics and Bio-Informatics, pp. 1143-1148, 2005.

[10] N. Vasudha, "Applied Mathematical Sciences", 
Vol. 6, pp. 5835-5840, 2012.

[11] M. Talbi, A. Aouinet, L. Salhi and A. Cherif, "New Method of R-Wave Detection by Continuous Wavelet Transform", Signal Processing International Journal, Vol. 6, pp. 165-173, 2011.

[12] B. Moon, Y. Jin, J. Ryu, "Implement of Vehicle Sensor System Using Wireless Communication and Mobile Device", J. of the Korean Industrial Information System, Vol. 14, No. 2, pp. 51-58, 2009.

[13] K. Jung, J. Lee, Y. Kim, Y. Sohn, W. Lee and S. Heo, "Design and Implementation of tiny UDP/IPv6 Protocol for Sensor Networks", J. of the Korean Industrial Information System, Vol 13, No. 4, pp. 73-82, 2008.

[14] S. Mallat, "A Theory for Multiresolution Signal Decomposition: The Wavelet Representation", IEEE Trans. Pattern Reco. and Machine Int., Vol. 11, pp. 674-693, 1989.

[15] S. Mallat and W. Hwang, "Singularity detection and processing with wavelets", IEEE Trans. Inf. Theory, Vol. 38, pp. 617-643, 1992.

[16] S. park and S. Park, "An Image Coding Method by Using the 4 Bit-Level Information of Wavelet Coefficients", Journal of the Korea Industrial Information System Society, Vol. 16, pp. 23-33, 2011.

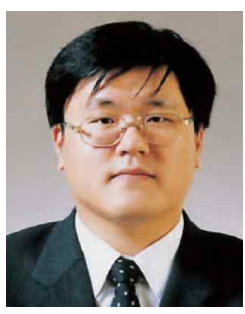

조 영 창 (Young Chang Cho)

- 정회원

- 영남대학교 전기공학과 공학사

- 영남대학교 전자공학과 공학석사

- 영남대학교 전자공학과 공학박사

- 경운대학교 항공대학 항공정보통신공학과 교수

- 관심분야 : $\mathrm{DSP}$, 심전도 신호처리

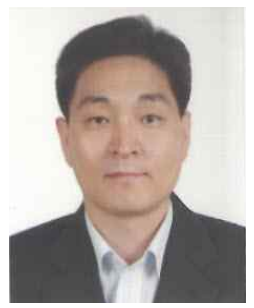

김 민 수 (Min Soo Kim)

- 정회원

- 경일대학교 전기공학과 공학사

- 영남대학교 전기공학과 공학석사

- 영남대학교 전자공학과 공학박사

- 경운대학교 항공대학 항공정보통신공학과 교수

- 관심분야 : 생체임피던스, 생체신호처리

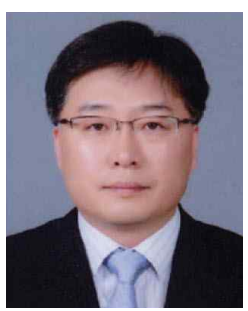

윤 정 오 (Jeong Oh Yoon)

- 정회원

- 경북대학교 전자공학과 공학사

- 경북대학교 전자공학과 공학석사

- 경북대학교 전자공학과 공학박사

- 경운대학교 항공대학 항공정보통신공학과 교수

- 관심분야 : DSP, 영상신호처리

논 문 접 수 일 : 2013년 09월 11일 1차수정 완료일 : 2014년 01월 20일 2차수정 완료일 : 2014년 02월 20일 게 재 확 정 일 : 2014년 02월 24일 